\title{
EM TEMPOS DE REFLEXÃO... DESPEDIDA? NÃO, CONTINUIDADE!
}

\author{
Caríssimos/as Leitores/as,
}

Chegamos à última edição de e-Mosaicos em 2019. Ela nos traz o dossiê temático "Ensino Médio: passos e impasses na atualidade", organizado pelos professores Gaudêncio Frigotto e Marise Ramos, a quem muito agradecemos pela parceria.

No contexto atual, em que é mais do que necessário refletir e dialogar sobre o lugar do Ensino Médio e de sua condição de oferta no atual cenário da educação brasileira, registramos nosso orgulho com o trabalho realizado em prol desta edição. Precisamos ressaltar que, devido à grande quantidade de artigos submetidos, optamos por dividir a publicação. Dessa forma, além deste dossiê temático, outros artigos aprovados serão publicados em edições de 2020 de e-Mosaicos.

Convidamos cada leitor a conhecer a apresentação desta edição por meio da leitura das páginas que se seguem a esta, escrita pelos professores organizadores deste dossiê.

Dois mil e vinte se aproxima e, com sua chegada, anunciamos novas mudanças em e-Mosaicos. A partir de agora, despedimo-nos da editoria geral da revista a que estivemos à frente desde seu primeiro número, em 2012. Foram muitos desafios, aprendizados e compartilhamentos. Foram alegrias comemoradas com as indexações e com o reconhecimento do B1 no primeiro Qualis/CAPES e tantas outras histórias poderiam ser contadas aqui nessas breves linhas. Todavia, mais do que continuar a tecêlas, optamos por anunciar que, a partir de janeiro próximo, o Professor Lincoln Tavares Silva, sem dúvida, um dos principais responsáveis pela existência da e-Mosaicos, se não, o primeiro (ou um dos primeiros) a sonhar esse sonho lá pelos idos de 2006, assumirá a editoria geral de e-Mosaicos. Ao Professor Lincoln Tavares Silva, desejamos excelente condução dos próximos anos de e-Mosaicos.

E, antes de concluir a escrita deste editorial, ousamos dizer que há pessoas que, com sua leveza e movimento agregador, escrevem uma história que fica guardada nas nossas memórias. A professora Jacqueline de Fátima dos Santos Morais é uma dessas pessoas. A ela, sempre solícita aos chamados desta editoria para atuar emitindo seus pareceres aos artigos submetidos à e-Mosaicos, registramos nosso muito obrigada! Jacqueline, presente!

Aos nossos leitores, fica a reafirmação do convite para que continuemos tecendo diálogos e construindo cotidianamente a e-Mosaicos como um espaço formativo.

Para encerrar essas palavras, desejamos ótima leitura e que cada um de nós possa viver o sentido pleno do Natal e que o novo ano que se avizinha seja pleno de realizações pessoais e profissionais.

Andrea da Paixão Fernandes Editora Geral e-Mosaicos - Revista Multidisciplinar de Ensino, Pesquisa, Extensão e Cultura do Instituto de Aplicação Fernando Rodrigues da Silveira (CAp-UERJ) 